\title{
Detection of marine birnavirus genome in zooplankton collected from the Uwa Sea, Japan
}

\author{
Shin-Ichi Kitamura, Shin-Ichiro Kamata, Shin-Ichi Nakano, Satoru Suzuki* \\ Center for Marine Environmental Studies, Ehime University, Matsuyama 790-8577, Japan
}

\begin{abstract}
Marine birnaviruses (MABVs) infect a wide range of fish and shellfish, yet their mode of transmission is still unclear. To determine whether marine plankton serve as a vector for MABVs, we examined plankton collected from the Uwa Sea, Japan. The phytoplankton and zooplankton were collected monthly, at depths of 0 and $40 \mathrm{~m}$, from May to November 2001. Detection of the MABV genome was carried out using 2-step PCR and virus isolation. Viral genome was detected in zooplankton collected at $0 \mathrm{~m}$ depth in September and at $40 \mathrm{~m}$ depth in November. The virus could not be isolated in the PCR-positive samples. These results suggest that zooplankton may act as a vector of MABVs, although the infective and/or accumulated virus titer in zooplankton was low.
\end{abstract}

KEY WORDS: Birnavirus - Plankton - Reservoir - Vector · Uwa Sea

Resale or republication not permitted without written consent of the publisher

The marine birnavirus (MABV) group, a member of the Birnaviridae, are icosahedral unenveloped viruses whose genomes comprise 2 segments of doublestranded RNA designated A and B (Dobos et al. 1979). One example of MABV is the Yellowtail ascites virus (YAV), first isolated from diseased yellowtail Seriola quiqueradiata in Japan in 1985 (Sorimachi \& Hara 1985). Since then, other similar birnaviruses have been isolated from many diseased fish and shellfish around the world (Castric et al. 1987, Sohn et al. 1995, Suzuki et al. 1998). Jung et al. (2001) reported that an MABV was isolated from diseased sea squirts Halocynthia roretzi in Korea. These findings suggest that MABVs have a broad host range among marine organisms. We suspect that plankton may serve as a vector of MABVs, because plankton are the food of most juvenile fish and shellfish. However, the mode by which MABVs are transmitted remains unclear. It is important to identify this mode in order to prevent MABV-caused diseases. This study aims to determine if MABVs are present in plankton.
Materials and methods. Monitoring of basic physico-chemical and biological data: We sampled plankton at a single sampling station in Uchiumi Bay, on the west coast of Ehime Prefecture, Shikoku Island, Japan, from May to November 2001. Water temperature and salinity were measured using a Chlorotech (Arec Electronics ACL- 208-DK) profiler. Chlorophyll a was measured according to Moran \& Porath (1980). Plankton were collected between 0 and $2 \mathrm{~m}$ depth, and between 40 and $45 \mathrm{~m}$ depth, using 2 plankton nets of $20 \mu \mathrm{m}$ and $200 \mu \mathrm{m}$, respectively. Samplings were performed 40 times at each depth. Zooplankton were sorted out under a stereomicroscope. This procedure was repeated twice. The dominant phytoplankton and zooplankton were monitored monthly.

Two-step PCR: RNA extraction and PCR were performed according to Suzuki et al. (1997a). Briefly, collected plankton were washed with artificial seawater 3 times and dried, then $400 \mu \mathrm{g}$ plankton was homogenized and suspended in $45 \mu \mathrm{TE}(0.2 \mathrm{M}$ Tris $\mathrm{HCl}, \mathrm{pH}$ 8.3, 0.1 M EDTA) buffer. Five $\mu \mathrm{l}$ proteinase K (10 mg $\mathrm{ml}^{-1}$, TaKaRa) was added. The mixture was incubated at $55^{\circ} \mathrm{C}$ for $2 \mathrm{~h}$. Nucleic acids were extracted using the phenol-chloroform method. The extracted nucleic acid was heated at $100^{\circ} \mathrm{C}$ for 5 min with the addition of a primer set of P1-P2 (P1; 5' -AGAGATCACTGACTTCACAAGTGAC-3', and P2; 5'-TGTGCACCACAGGAAA GATGACTC-3') following reverse transcription (RT) performed with Moloney murine leukaemia virus reverse transcriptase (MMLV, GIBCO) at $37^{\circ} \mathrm{C}$ for $1 \mathrm{~h}$. To inactivate the reverse transcriptase, the sample was heated at $100^{\circ} \mathrm{C}$ for $5 \mathrm{~min}$. The synthesized cDNA was employed for PCR. PCR amplification was performed in a DNA thermal cycler (TaKaRa) with 30 amplification cycles $\left(95^{\circ} \mathrm{C}\right.$ for $1 \mathrm{~min}, 50^{\circ} \mathrm{C}$ for $1 \mathrm{~min}$, and $72^{\circ} \mathrm{C}$ for $1 \mathrm{~min})$. A $5 \mu \mathrm{l}$ portion of the RT-PCR product was employed for nested-PCR. The nested amplification with 30 cycles was conducted at $95^{\circ} \mathrm{C}$ for $1 \mathrm{~min}, 48^{\circ} \mathrm{C}$ 
Table 1. Basic physico-chemical and biological data at 0 and $40 \mathrm{~m}$ depth at the sampling station in 2001

\begin{tabular}{|c|c|c|c|c|c|c|c|c|c|c|}
\hline & \multicolumn{2}{|c|}{ Water temp. $\left({ }^{\circ} \mathrm{C}\right)$} & \multicolumn{2}{|c|}{ Salinity $\left(\mathrm{mg} \mathrm{l}^{-1}\right)$} & \multicolumn{2}{|c|}{$\mathrm{Chl} a\left(\mu g \mathrm{l}^{-1}\right)$} & \multicolumn{2}{|c|}{ Dominant phytoplankton } & \multicolumn{2}{|c|}{ Dominant zooplankton } \\
\hline & $0 \mathrm{~m}$ & $40 \mathrm{~m}$ & $0 \mathrm{~m}$ & $40 \mathrm{~m}$ & $0 \mathrm{~m}$ & $40 \mathrm{~m}$ & $0 \mathrm{~m}$ & $40 \mathrm{~m}$ & $0 \mathrm{~m}$ & $40 \mathrm{~m}$ \\
\hline May & 22.64 & 20.39 & 34.20 & 34.30 & 3.47 & 0.38 & Chaetoceros & Chaetoceros & Noctiluca & Oithona \\
\hline July & 26.97 & 20.99 & 33.60 & 34.21 & 0.40 & 0.26 & Chaetoceros & Chaetoceros & Paracalanus & Paracalanus \\
\hline September & 26.17 & 26.30 & 32.73 & 33.75 & 0.79 & 0.49 & Chaetoceros & Chaetoceros & Oithona & Oithona \\
\hline November & 19.94 & 19.91 & 34.22 & 34.21 & 0.54 & 0.45 & Thalassiosira & Thalassiosira & Oithona & Oithona \\
\hline
\end{tabular}

for $1 \mathrm{~min}$, and $72^{\circ} \mathrm{C}$ for $1 \mathrm{~min}$ with a primer set of P3-P4 (P3; 5'-CAACACTCTTCCCCATG-3', P4; 5'-AGAACCTCCCAGTGTCT-3'). The purity and size of the amplified products were assessed using electrophoresis on $2 \%$ agarose gel. The gel was stained with ethidium bromide and visually examined under UV light.

Nucleotide sequencing: To perform nucleotide sequencing, the amplified PCR fragment (168 bp) was cut from the gel under the long wavelength of UV and was purified using Ultrafree-DA (Millipore). Sequencing was performed based on the dideoxy nucleotide termination method (Sanger et al. 1977) in an automated ABI PRISM 310 DNA sequencer (PE Biosystems) using the ABI PRISM BigDye Terminator Cycle Sequencing FS Ready Reaction Kit (PE Biosystems) and primer set of P3-P4 described above. Analysis of the results was performed using Genetyx Mac Version 8.0 software. The sequencing was carried out at the Center for Gene Research, Ehime University, Japan.

Cell culture: The chinook salmon embryo cell line (CHSE-214) was used for isolating the MABV in the PCR-positive samples. The cells were grown at $20^{\circ} \mathrm{C}$ in Eagle's minimum essential medium (MEM, Nissui)

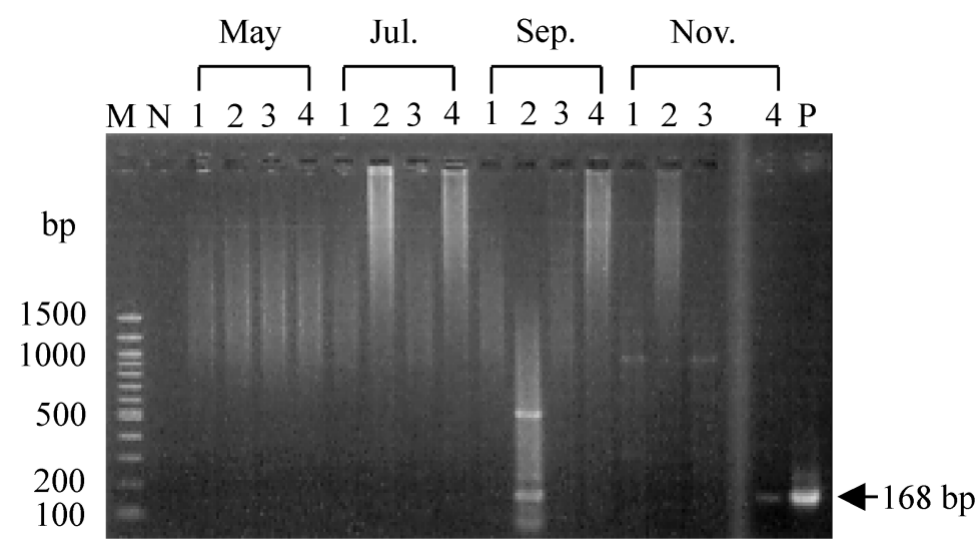

Fig. 1. Detection of the marine birnavirus (MABV) genome by 2-step PCR in plankton collected at 0 to $2 \mathrm{~m}$ and 40 to $45 \mathrm{~m}$ depth. Lanes: M, molecular marker; N: negative control without template; (1) phytoplankton collected at 0 to $2 \mathrm{~m}_{\text {; }}(2)$ zooplankton collected at 0 to $2 \mathrm{~m}_{\text {; }}$ (3) phytoplankton collected at 40 to $45 \mathrm{~m}_{\text {; }}$ (4) zooplankton collected at 40 to $45 \mathrm{~m}$; P: positive control; MABV Y-6 strain, isolated from yellowtail containing $10 \%$ fetal bovine serum (FBS). Plankton from PCR-positive samples were homogenized in a 1000 -fold volume of MEM, and the homogenate was centrifuged at $3000 \times g$ at $4^{\circ} \mathrm{C}$ for $15 \mathrm{~min}$. The supernatant was filtered through a $0.45 \mu \mathrm{m}$ pore filter (Millipore). A $500 \mu \mathrm{l}$ portion of the filtrate was inoculated to a monolayer of CHSE-214 cells cultured in a $25 \mathrm{~cm}^{2}$ flask (Corning), which were incubated at $20^{\circ} \mathrm{C}$ for 2 wk. The cells were monitored daily for cytopathic effect (CPE). When CPE was not observed, blind passage was performed.

Results and discussion. Basic physico-chemical and biological data collected at the sampling station are shown in Table 1. Water temperature reached a maximum in July at $0 \mathrm{~m}$ depth, and thermal stratification developed between May and July. The water temperatures in September and November were isothermal, probably due to vertical mixing. Salinity was almost constant during the study period. Chlorophyll a concentrations were highest at $0 \mathrm{~m}$ depth in May. The dominant phytoplankton during the experimental period was Chaetoceros spp., except in November, when Thalassiosira spp. was dominant. In September and November, the dominant zooplankton was Oithona spp.

The results of testing for the MABV genome by 2 -step PCR in the plankton are shown in Fig. 1. Positives were not detected from phytoplankton. MABV genome was detected in zooplankton collected at $0 \mathrm{~m}$ depth in September and $40 \mathrm{~m}$ depth in November. In this experiment, the PCRpositive sample was only 2 out of 8 zooplankton, which is a low positive rate. However, we obtained similar data in 1999. Zooplankton were collected at the same station in July, September, October and November 1999. MABV genome was detected in zooplankton collected in September and November. The PCR-positive sample was 4 out of 12 (33.3\%) zooplankton. This additional supporting evidence leads us to conclude that MABV either infects or is concentrated in zooplankton. The seawater containing PCR-positive plankton 
(A)

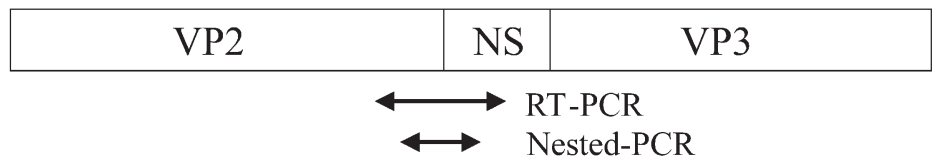

(B)

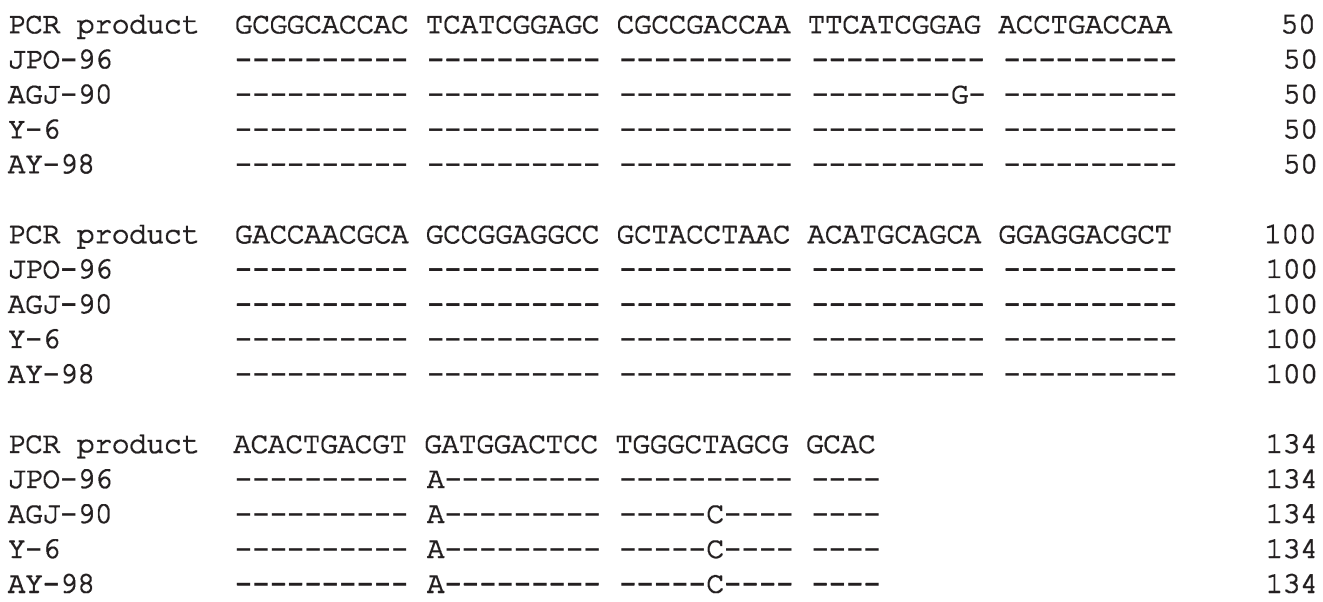

Fig. 2. (A) Map of segment A of aquabirnavirus and the PCR region. (B) Nucleotide sequences of the 2-step PCR products and the isolated strains. Sequences obtained in September and November were the same. Strains JPO-96, AGJ-90, Y-6 and AY98 were used for comparison. - : same base as in PCR-product

was filtered to remove plankton. PCR was then employed to confirm that the seawater itself was not origin of the virus. MABV genome was not detected in the seawater, which indicates that the MABV genome originated in plankton. Furthermore, the large band was observed in the September sample (Fig. 1, lane 'Sep. 2'). This band was sequenced, but no homologous sequences were found in DDBJ. This indicates that the band is non-specific, probably derived from plankton DNA.

This is the first report about MABV genome detected in identified zooplankton. White spot syndrome virus (WSSV), which is an important pathogen in shrimp, can infect copepods (Lo et al. 1996), and fish nodavirus can infect zooplankton such as artemia Salina nauplii and the rotifer Brachionus plicatilis (Skliris \& Ricards 1998). Since both viruses are crustacean viruses, it is reasonable that they infect crustacean plankton. MABVs have a broad host range, which includes fish, molluscan shellfish and protochordates, but are not known to infect crustaceans. Still, it is not clear whether the MABV infected or was accumulated in zooplankton. The virus infectivity titer in plankton should be low, because the virus was not isolated from PCR-positive zooplankton (data not shown). MABV genome was detected in September and November, but not in May and July. This suggests that MABV infection and/or accumulation in zooplankton varies seasonally. It is thought that zooplankton containing the MABV group increased in abundance from autumn to winter in the Uwa Sea. The habitat depth of the infected zooplankton also varied; the viral genome was detected in zooplankton collected at $0 \mathrm{~m}$ in September, and at $40 \mathrm{~m}$ depth in November. Zooplankton such as copepods show patchy distribution in the water column and diel vertical migration. It is therefore possible that we sampled the zooplankton from a patch.

The junction region between the genes VP2 and NS (Fig. 2A) is variable, but useful for the genogrouping of aquabirnaviruses (Heppell et al. 1992, 1993, Hosono et al. 1996). The sequence data from the present study were compared with some MABV strains isolated from fish and shellfish around western Japan (Fig. 2B). The sequences of the 2nd PCR-positive samples were the same. When compared with all reference strains, the 111th base was $G$, although there was no amino acid change. The difference between JPO-96 (Suzuki et al. 1998) isolated from the Japanese pearl oyster and the PCR-product in this study was only at the aforementioned 111th base. Also, AGJ-90 (Suzuki et al. 1997b) isolated from the agemaki (jack knife clam) Sinonovacura constrica showed that the 39th base was $\mathrm{G}$ and the 126th base was $C$, whereas these were $A$ and $T$ in the present study. Fish origin strains Y-6 (Hosono et al. 
1996) isolated from the yellowtail and AY-98 (Jung et al. 1999) isolated from the ayu Plecoglossus altivelis had $\mathrm{C}$ at the 126th base, whereas the PCR products in our study had a $\mathrm{T}$ at this base. The highly conserved sequences among the MABV strains suggest that MABVs occurring in western Japan might be genetically similar.

In summary, MABV genome was detected in zooplankton. The number of zooplankton containing the MABV group increased from autumn to winter. The sequence analysis of the MABV genome in the plankton was similar to those of MABVs isolated from western Japan in previous studies. These results suggest that zooplankton may serve as a vector of MABVs in these areas. The infective state of MABVs in zooplankton will be further examined in the future.

Acknowledgements. We thank J. Bower, Hokkaido University, for his review of this manuscript, and K. Hyodo, T. Hirose and the staff of the Uchiumi Institute of Oceanic and Fishery Science for allowing us to use their facilities for our research. We also thank the members of the Umi Group, CMES, Ehime University, for their encouragement throughout this study. This work was partly supported by Grants-in-Aid from MEXT, Japan, and the Sasakawa Scientific Research Grant from The Japan Science Society.

\section{LITERATURE CITED}

Castric J, Baudin-Laurencin F, Coustans MF, Auffret M (1987) Isolation of infectious pancreatic necrosis virus, $\mathrm{Ab}$ serotype, from an epizootic in farmed turbot (Scophthalmus maximus). Aquaculture 67:117-126

Dobos P, Hill BJ, Hallett R, Kells DTC, Becht H, Teninges D (1979) Biophysical and biochemical characterization of five animal viruses with bisegmented double-stranded RNA genomes. J Virol 32:593-605

Heppell J, Berthiaume L, Tarrab E, Lecomte J, Arella M (1992) Evidence of genomic variations between infectious pancreatic necrosis virus strains determined by restriction fragment profiles. J Gen Virol 73:2863-2870

Heppell J, Berthiaume L, Corbin F, Tarrab E, Lecomte J,

Editorial responsibility: Jo-Ann Leong,

Kaneohe, Hawaii, USA
Arella M (1993) Comparison of amino acid sequences deduced from a cDNA fragment from infectious pancreatic necrosis virus (IPNV) strains of different serotypes. Virology 195:840-844

Hosono N, Suzuki S, Kusuda R (1996) Genogrouping of birnaviruses isolated from marine fish: a comparison of VP2/NS junction regions on genome segment A. J Fish Dis 19:295-302

Jung SJ, Kitamura SI, Kawai K, Suzuki S (1999) Isolation of different types of birnavirus from ayu Plecoglossus altivelis and amago salmon Oncorhynchus rhodurus cultured in the same geographic area. Dis Aquat Org 38:87-91

Jung SJ, Oh MJ, Date T, Suzuki S (2001) Isolation of marine birnavirus from sea squirts Halocynthia roretzi. In: Sawada $\mathrm{H}$, Yokosawa H, Lambert CC (eds) The biology of ascidians. Springer-Verlag, Tokyo, p 436-441

Lo CF, Ho CH, Peng SE, Chen $\mathrm{CH}$ and 8 others (1996) Infection of white spot syndrome baculovirus (WSBV) detected in cultured and captured shrimps, crabs and other arthropods. Dis Aquat Org 27:215-225

Moran R, Porath D (1980) Chlorophyll determination in intact tissues using N,N-Dimethylformamide. Plant Physiol 65: 478-479

Sanger F, Nicklen S, Coulson AR (1977) DNA sequencing with chain-termination inhibitor. Proc Natl Acad Sci USA 75:5463-5467

Skliris GP, Richards RH (1998) Assessment of the susceptibility of the brine shrimp Artemia salina and rotifer Brachionus plicatilis to experimental nodavirus infections. Aquaculture 169:133-141

Sohn SJ, Park MA, Do JW, Choi JY, Park JW (1995) Birnavirus isolated from cultured flounder in Korea. Fish Pathol 30: 279-280

Sorimachi M, Hara T (1985) Characteristics and pathogenicity of virus isolated from yellowtail fingerlings showing ascites. Fish Pathol 19:231-238

Suzuki S, Hosono N, Kusuda R (1997a) Detection of aquatic birnavirus gene from marine fish using a combination of reverse transcription-and nested PCR. J Mar Biotechnol 5:205-209

Suzuki S, Nakata T, Kamakura M, Yoshimoto M, Furukawa Y, Yamashita Y, Kusuda R (1997b) Isolation of birnavirus from agemaki (jack knife clam) Sinonovacura constica and survey of the virus using PCR technique. Fish Sci (Tokyo) 63:563-566

Suzuki S, Kamakura M, Kusuda R (1998) Isolation of birnavirus from Japanese pearl oyster Pinctada fucata. Fish Sci (Tokyo) 64(2):342-343

Submitted: March 25, 2002; Accepted: September 24, 2002 Proofs received from author(s): February 17, 2003 